кандидат педагогічних наук, доцент

(Рівненський державний гуманітарний університет) pavelkiv.kegmail.com

ORCID: 0000-0002-9112-2542

\title{
ІНШОМОВНА ПІДГОТОВКА ФАХІВЦІВ СОЦІАЛЬНОЇ СФЕРИ В СВІТЛІ ДІЯЛЬНІСНОГО ПІДХОДУ
}

У статті розглянуто зміст і сутність діяльнісного підходу до іншомовної комунікаиії майбутніх фахівців соціальної сфери. Обтрунтовано сутність іншомовної комунікації як особливого виду діяльності під впливом когнітивних, сочіально-психологічних та особистісних статусів учасників комунікації. Відзначено, ще при цьому іншомовний характер комунікаџиї накладає на неї ще й додаткову соџіальнолінгвістичну й соиіокультурну специфіку. 3'ясовано праксеологічний контекст іншомовної підготовки майбутніх фахівців соціальної сфери; визначено асоиіативний ряд практичної діяльності та суміжних понять (взаємодія, спілкування, життєтворчість, динамічні зміни) у контексті іншомовної комунікативної діяльності. Дослідження діяльнісного аспекту іншомовної комунікативної діяльності уможливило обтрунтування взаємозв'язку елементарних компонентів комунікаиії та іншомовної комунікативної діяльності майбутніх фахівиів соиіальної сфери.

Ключові слова: діяльність, комунікація, фахівиі сочіальної сфери, іншомовна комунікативна діяльність.

Актуальність та постановка проблеми дослідження. Сучасне суспільство відчуває гостру потребу в кваліфікованих фахівцях соціальної сфери, зважаючи на постійну кількісну і якісну динаміку соціальних проблем, накопичених різними прошарками населення. Означена динаміка, однак, має характер внутрішньосуспільний, визначається сукупністю соціально-економічних та соціальнополітичних чинників, що впливають на соціальне благополуччя людини в Україні. Водночас система соціального захисту в нашій державі дедалі більше уніфікується, наближаючись до міжнародних стандартів, - і за змістом, і за характеристиками. Ця уніфікація потребує сьогодні всебічно обізнаного, компетентного фахівця, а система вищої освіти має гарантувати таку підготовку в усіх відношеннях. Натомість можемо констатувати, що формування професійної компетентності майбутніх фахівців соціальної сфери наражається на низку ризиків і викликів, серед яких і низький рівень іншомовної компетентності, нездатність працювати в іншомовному середовищі, неможливість ознайомитися i впровадити кращий світовий досвід 3 причини незнання іноземних мов (передовсім, звичайно, англійської).

3 іншого боку, іншомовна комунікація - це особливий вид діяльності, при тому діяльності комунікативної, яка передбачає вплив когнітивних, соціально-психологічних та особистісних статусів учасників комунікації; при цьому іншомовний характер комунікації накладає на неї ще й додаткову специфіку - соціально-лінгвістичну й соціокультурну.

Питання перебігу іншомовної комунікації, характеристик ії учасників, головних стимулюючих та гальмуючих чинників, формування іншомовної комунікативної компетентності стали предметом дослідження багатьох учених - в Україні та поза ії межами. Такий інтерес до проблеми викликаний, на нашу думку, загальноєвропейським нормативно-правовим полем іншомовної комунікації на рівні ключових та життєвих компетенцій, з одного боку, та загальними глобалізаційними світовими процесами - 3 іншого. Так, іншомовну комунікацію як лінгвістичну проблему досліджували і досліджують Микола Бахтін [1], Флорій Бацевич [2], Богран Робер-Ален, де [3], Дейк Тойн А., ван [4], Олексій Леонтьєв [5], Морсон Гаррі Сол, Емерсон Керіл [6], Хомський Аврам Ноам [7] та інші вітчизняні і зарубіжні дослідники; питання іншомовної комунікативної компетенції розглядаються в наукових розвідках В. Богданова [8], Т.Вольфовської [9], В. Гез [10], Т. Колодько [11], Л. Мамчур [12], Д. Хаймса [13], А. Шумарової [14] та ін. Водночас маємо зауважити, що поза увагою науковців залишається переважна більшість питань іншомовної підготовки фахівців для соціальної сфери як особливого комунікативного середовища, де здійснюються соціальні і професійні комунікації іноземними мовами. Заслуговує на увагу постановка питання про комунікацію у соціальній сфері та підготовку до неї як особливі види діяльності, що мають реалізуватися в іншомовному середовищі закладу вищої освіти, який має на меті підготовку висококваліфікованих фахівців соціальної сфери. У зв'язку з цим перед статтею поставлено мету - визначити зміст та основні характеристики діяльнісного підходу до формування іншомовної компетентності майбутніх фахівців соціальної сфери, виходячи з ії специфіки з огляду на майбутню професійну діяльність у соціальному комунікативному просторі.

Виклад основного тексту. Діяльнісні основи професійної підготовки фахівців досить добре розроблені в теорії і методології сучасної педагогічної науки, починаючи зі здобутків радянських вчених-психологів (С. Рубінштейна [15], О. Леонтьєва [5] та ін.), та філософів (Г. Батищева [16], 
Е. Юдіна [17] та ін.) До грунтовних наукових розвідок у цій сфері відносимо роботи О. Брушлинського [18], В. Давидова [19], І. Зязюна [20], О. Пехоти [21] та ін.

Для нас важливим $є$ твердження розробників діяльнісного підходу (О. Боровських, М. Розов [22]) про те, що це не лише функція індивіда, але й суспільства; у такому разі не лише професійна підготовка фахівців соціальної сфери, але й їх професійна діяльність може розглядатися в контексті діяльнісного підходу. У найширшому розумінні діяльність (за Р. Бограном [3], Т. Дейком [4], Г. Богіним [23] та ін.) це сукупність дій, які не можуть відбутися самі по собі і змінюють ситуацію чи навпаки, перешкоджають певним змінам, які відбуватимуться самі по собі, якщо діяльність не буде вчинена.

Специфіка нашого дослідження, присвяченого іншомовній підготовці майбутніх фахівців соціальної сфери, у цьому відношенні двояка: з одного боку, маємо аналізувати не просто діяльність у загальному вигляді, а комунікативну діяльність; з іншого - це комунікативна діяльність у соціальній сфері.

Іерархія цих понять у контексті діяльнісного підходу може бути викладена у ланцюгу ДІЯЛЬНІСТЬ $\rightarrow$ ІНШОМОВНА КОМУНІКАТИВНА ДІЯЛЬНІСТЬ $\rightarrow$ ІНШОМОВНА КОМУНІКАТИВНА ДІЯЛЬНІСТЬ У СОЦІАЛЬНІЙ СФЕРІ. Дедуктивна реалізація означеної ієрархії базових понять звертає нас, передовсім, до поняття діяльності. Як було зазначено вище, це поняття було досліджене, насамперед, у площині філософії та психології, завдяки чому встановилося праксеологічне поле дослідження діяльнісних процесів у соціальному, культурному, економічному контексті. Як стверджує T. Мартинюк [24], сучасна праксеологія - це наука про організовану діяльність, тому праксеологічний контекст іншомовної підготовки майбутніх фахівців соціальної сфери в діяльнісному контексті для нас такий суттєвий. Педагогічний зміст діяльності у контексті проблеми нашого дослідження влучно сформульований у дисертаційному дослідженні Т.Мартинюк таким чином: "діяльність з будь-якого приводу $є$ наслідком незадоволення індивідом існуючого стану речей й свідчить про готовність індивіда змінити обставини за власним бажанням, i як наслідок відбувається програмування кращого майбутнього" [24: 22].

Особливе місце в діяльнісному підході до проблеми нашого дослідження займає його практичний контекст; діяльність як практика стала основою діалектичного погляду на цей феномен. У площині практики діяльність викликає асоціативні поєднання з поняттями взаємодії, спілкування, життєтворчості, динамічних змін тощо. Ці асоціативні ряди безпосередньо пов'язані з іншомовною комунікативною діяльністю у соціальній сфері, тому відображають понятійний простір нашого дослідження (рис. 1).

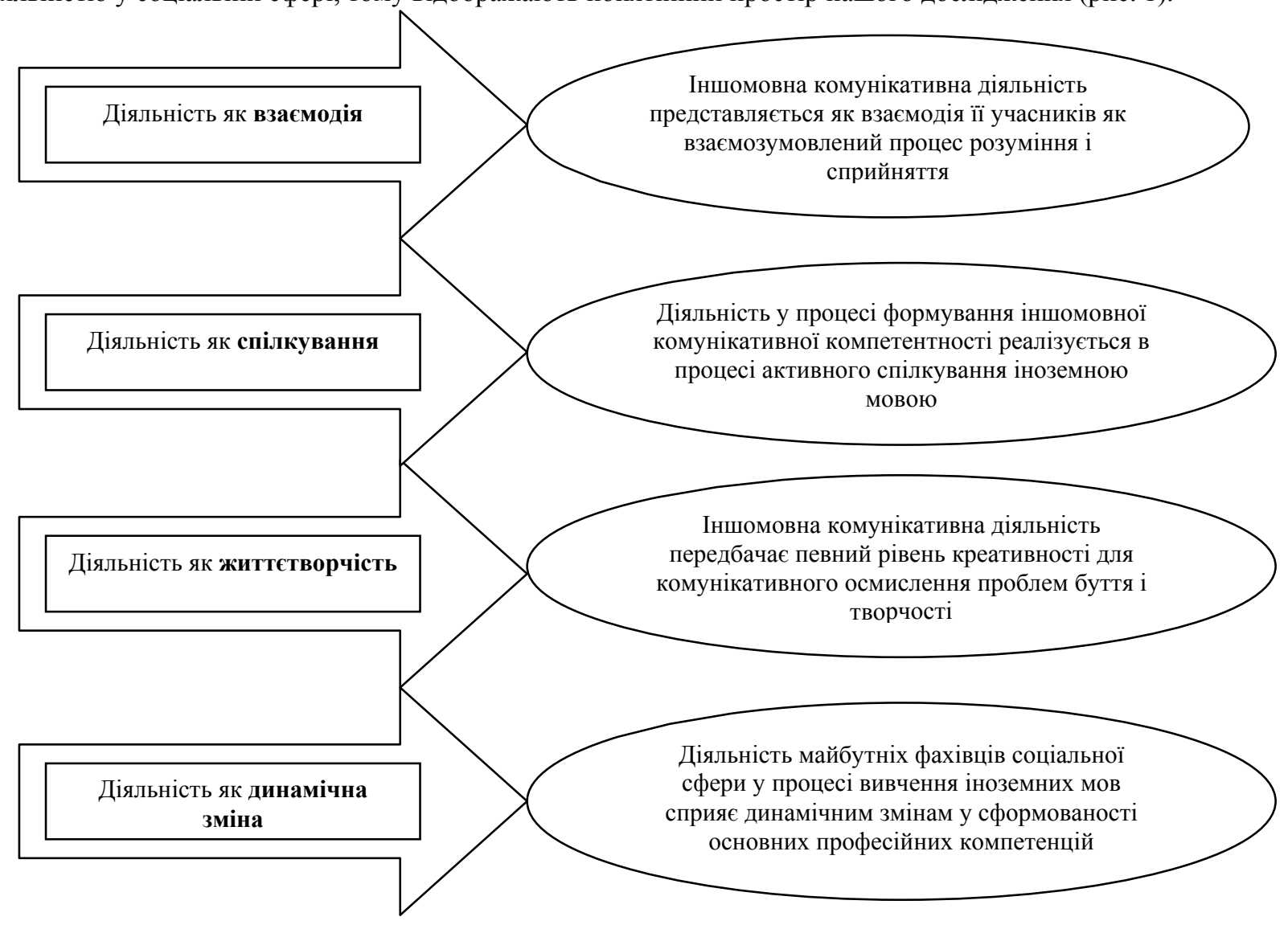

Рис. 1. Асоціативний ряд практичної діяльності та суміжних понять у контексті іншомовної комунікативної діяльності майбутніх фахівців соціальної сфери 
Другий рівень діяльнісного понятійного підходу, як свідчить зазначена вище ієрархія, належить поняттю "комунікативна діяльність". Як свідчить наукова література, комунікативна діяльність - це досить широке поняття, яке не обов’язково передбачає мову як засіб комунікації (Б.Норман, 1996 [25]). Проте у межах проблеми нашого дослідження ми розглядаємо саме мовну комунікативну діяльність: тому в іiі структурі важливо вирізняти мовленнєві дії, мовленнєві операції, мовленнєвий акт, мовленнєві ситуації. Ці діяльнісні характеристики комунікативної діяльності набирають своєї специфіки, якщо йдеться про спілкування іноземними мовами, оскільки мовлення залежить в такому разі не лише від предмета, мети й каналів комунікації, але й від рівня іншомовної підготовленості суб'єктів комунікації, іншомовних засобів комунікації тощо.

Взаємозв’язок елементарних компонентів комунікації (в усному й писемному діловому спілкуванні [26]) та іншомовної комунікативної діяльності майбутніх фахівців соціальної сфери викладено в таблиці 1 .

Таблиця 1.

Взаємозв'язок елементарних компонентів комунікації та іншомовної комунікативної діяльності майбутніх фахівців соціальної сфери

\begin{tabular}{|c|c|c|}
\hline $\begin{array}{l}\text { Компоненти } \\
\text { процесу } \\
\text { спілкування } \\
\end{array}$ & Їх сутнісна характеристика & $\begin{array}{c}\text { Зв'язок з іншомовною комунікативною } \\
\text { діяльністю фахівців соціальної сфери }\end{array}$ \\
\hline $\begin{array}{l}\text { Суб’єкт } \\
\text { спілкування }\end{array}$ & $\begin{array}{l}\text { Це комунікатор, котрий створює і } \\
\text { передає інформацію в ході } \\
\text { комунікативного акту, кодуючи і } \\
\text { видозмінюючи ії залежно від } \\
\text { контексту і специфіки інших учасників } \\
\text { комунікації }\end{array}$ & $\begin{array}{l}\text { Специфіка суб’єктів іншомовної комунікації в } \\
\text { соціальній сфері полягає у тому, що вони } \\
\text { представляють соціальні послуги, } 3 \text { одного } \\
\text { боку, і соціальну проблему, що потребує } \\
\text { вирішення - з іншого }\end{array}$ \\
\hline $\begin{array}{l}\text { Об’єкт } \\
\text { спілкування }\end{array}$ & $\begin{array}{l}\text { Це особа, що сприймає інформацію у } \\
\text { процесі спілкування й інтерпретує іiі } \\
\text { залежно від змісту і форми подання } \\
\text { інформації, а також залежно від } \\
\text { особистісного сприйняття }\end{array}$ & $\begin{array}{l}\text { Об’єктом спілкування в }{ }^{2} \text { іншомовній } \\
\text { комунікації майбутніх фахівців соціальної } \\
\text { сфери виступають найчастіше самі ж } \\
\text { студенти і викладачі, що подають інформацію } \\
\text { іноземною мовою; рідше - фахівці соціальної } \\
\text { сфери чи клієнти (у процесі квазіпрофесійної } \\
\text { діяльності чи неформального навчання) }\end{array}$ \\
\hline $\begin{array}{l}\text { Предмет } \\
\text { спілкування }\end{array}$ & $\begin{array}{l}\text { Предметом спілкування є сукупність } \\
\text { його змісту, що підлягає передачі, } \\
\text { обговоренню, зміні та інтерпретації у } \\
\text { процесі комунікації }\end{array}$ & $\begin{array}{l}\text { Предметом спілкування в іншомовних } \\
\text { комунікаціях майбутніх фахівців соціальної } \\
\text { сфери виступають соціальні поняття, факти, } \\
\text { проблеми, значущі для студентів та їх } \\
\text { професійної діяльності }\end{array}$ \\
\hline $\begin{array}{l}\text { Засоби } \\
\text { спілкування }\end{array}$ & $\begin{array}{l}\text { Це способи кодування інформації, що } \\
\text { передається у процесі спілкування. } \\
\text { Провідним засобом спілкування є мова } \\
\text { (пряме спілкування), а також } \\
\text { спеціальні засоби та інструменти } \\
\text { (опосередковане спілкування) }\end{array}$ & $\begin{array}{l}\text { В ситуації іншомовного професійного } \\
\text { спілкування мова залишається провідним } \\
\text { засобом спілкування (проте має особливий } \\
\text { іншомовний і професійний зміст), а } \\
\text { спеціальні засоби (листування, аудіо-, } \\
\text { відеоінформація) набувають специфічного } \\
\text { змісту внаслідок необхідності їх залучення до } \\
\text { обговорення проблем діяльності в соціальній } \\
\text { сфері }\end{array}$ \\
\hline $\begin{array}{l}\text { Канали } \\
\text { комунікації }\end{array}$ & $\begin{array}{l}\text { Комунікація здійснюється } \\
\text { допомогою каналів комунікації, що } \\
\text { можуть бути окреслені як реалізовані } \\
\text { засоби комунікації-в просторі і часі }\end{array}$ & $\begin{array}{l}\text { Іншомовна комунікація майбутніх фахівців } \\
\text { соціальної сфери передбачає використання як } \\
\text { природних (словесних та невербальних), так і } \\
\text { штучних каналів іншомовної комунікації - } \\
\text { усних, документальних, віртуальних та ін. } \\
\text { Водночас є специфіка змісту цих комунікацій, } \\
\text { оскільки вони мають бути соціально й } \\
\text { професійно орієнтованими }\end{array}$ \\
\hline $\begin{array}{l}\text { Комунікативний } \\
\text { шум }\end{array}$ & 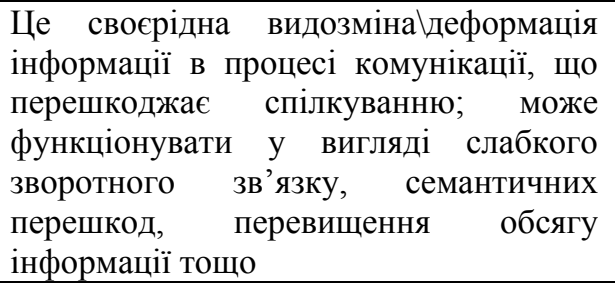 & 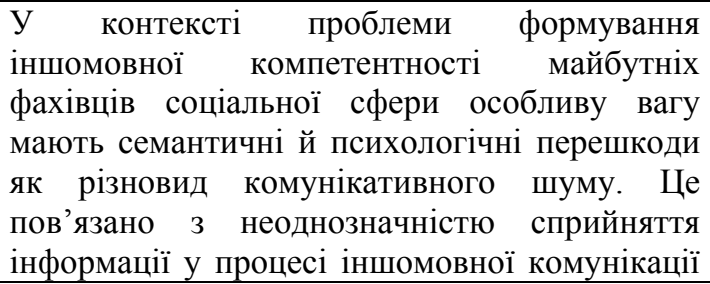 \\
\hline
\end{tabular}




\begin{tabular}{|c|c|c|}
\hline & & $\begin{array}{l}\text { - як на рівні термінів і понять, так і на рівні } \\
\text { психологічного несприйняття іншого суб'єкта } \\
\text { комунікації }\end{array}$ \\
\hline Фільтри & $\begin{array}{l}\text { Це способи відбору інформації для } \\
\text { комунікацій, що враховують інтереси } \\
\text { суб'єктів комунікації і обмежують иї на } \\
\text { інформаційному рівні. Можуть бути } \\
\text { внутрішньо-психологічними } \\
\text { зовнішніми соціокультурними }\end{array}$ & $\begin{array}{l}\text { Комунікативні фільтри в іншомовній } \\
\text { комунікації фахівців соціальної сфери дають } \\
\text { можливість уникати змісту поза межами } \\
\text { професійно-комунікативного поля соціальної } \\
\text { сфери }\end{array}$ \\
\hline $\begin{array}{l}\text { Зворотний } \\
\text { зв'язок }\end{array}$ & 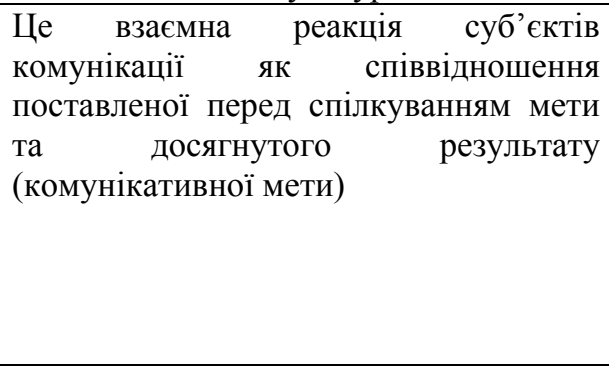 & $\begin{array}{l}\text { Зворотний зв'язок в іншомовній комунікації } \\
\text { студентів передбачає співвідношення } \\
\text { поставленої перед іншомовним спілкуванням } \\
\text { мети й результату комунікативного акту. При } \\
\text { цьому може бути позитивний зворотний } \\
\text { зв'язок (співучасник комунікації адекватно } \\
\begin{array}{l}\text { приймає їі результат) і негативний (інший } \\
\text { суб'єкт спілкування незадоволений його } \\
\text { результатами) }\end{array}\end{array}$ \\
\hline $\begin{array}{l}\text { Контекст } \\
\text { спілкування }\end{array}$ & \begin{tabular}{lrr} 
Контекст & спілкування & \multicolumn{2}{c}{ передбачає } \\
урахування & специфіки місця, часу та \\
iнших умов комунікативного процесу \\
(в тому $\quad$ числі & зовнішніх \\
соціокультурних & та & внутрішніх \\
індивідуально-психологічних)
\end{tabular} & $\begin{array}{l}\text { Соціокультурні зовнішні умови іншомовного } \\
\text { спілкування студентів залежать від } \\
\text { соціального контексту чи комунікаційного } \\
\text { фону. При цьому означений контекст } \\
\text { збагачується залежно від рівня початкової } \\
\text { іншомовної компетентності студентів, ї } \\
\text { здатності поповнювати свої знання і } \\
\text { комунікувати в іншомовному професійному } \\
\text { середовищі, рефлексувати щодо рівня своєї } \\
\text { іншомовної комунікативної компетентності }\end{array}$ \\
\hline $\begin{array}{l}\text { Продукт } \\
\text { спілкування }\end{array}$ & $\begin{array}{l}\text { Це результат комунікативного процесу } \\
\text { у матеріальному чи нематеріальному } \\
\text { вигляді }\end{array}$ & $\begin{array}{l}\text { Продуктом } \text { іншомовного } \\
\text { студентів - майбутніх фахівців соціальної } \\
\text { сфери - має стати сформована іншомовна } \\
\text { комунікативна компетентність }\end{array}$ \\
\hline
\end{tabular}

Діяльнісний підхід до іншомовної комунікації майбутніх фахівців соціальної сфери не виключає тристоронньої структури означеної комунікації у вигляді поєднання мотиваційної, цільової та реалізаційної (виконавчої) площин. Мотиващійна площина іншомовної комунікації студентів може бути представлена у вигляді макроінтенцій - загальних комунікативних намірів, які мають особистіснопрофесійний характер і можуть об’єднувати весь дискурс іншомовного спілкування майбутніх фахівців соціальної сфери. Означені макроінтенції, у свою чергу, характеризуються:

соціальною спрямованістю дискурсу - як у відношенні простого тезаурусу, так і у відношенні всього смислового навантаження комунікацій;

професійним змістом комунікативного наміру, його спрямованістю на основні соціальні проблеми, з якими буде мати справу фахівець соціальної сфери;

- особистісною мотивацією студента на оволодіння іншомовною комунікацією (з відносною часткою професійних зацікавлень та прагнення знати іноземну мову з причин, прямо не пов'язаних з майбутнім фахом).

Цільова площина комунікативної діяльності у контексті нашого дослідження втілює ідеалізований результат іншомовної комунікативної підготовки майбутніх фахівців соціальної сфери - високий рівень сформованості іншомовної комунікативної компетентності. Широке тлумачення поняття "соціальна сфера" дозволяє окреслити цю площину в кількох аспектах - інваріантному (суто професійному) та варіативному (особистісно-комунікативному). Такими чином, постановка кінцевої мети формування іншомовної компетентності студентів визначає і шляхи їі досягнення, втілені у виконавчій площині комунікативної діяльності. Ця площина являє собою динамічну сукупність конкретних дій і операцій 3 формування означеної компетентності у процесі іншомовного спілкування - в аудиторній чи позааудиторній формі. 
3 огляду на діяльнісний підхід до іншомовної підготовки майбутніх фахівців соціальної сфери важливою є поділ комунікативної діяльності на комунікативні (мовленнєві) дії. Як свідчать дослідження О. Леонтьєва [5: 45-48], мовленнєва дія має свої визначальні характеристики: цільову (підпорядкованість загальній меті комунікативної діяльності), структурну (детерміновану попередньою діяльністю, з одного боку, та загальною структурою комунікативної іншомовної діяльності), системну (визначає місце і роль окремої мовленнєвої дії в загальній структурі комунікативної діяльності) [27].

Висновок. Таким чином, нами розглянуто зміст і сутність діяльнісного підходу до іншомовної комунікативної діяльності майбутніх фахівців соціальної сфери. Обгрунтовано сутність іншомовної комунікації як особливого виду діяльності під впливом когнітивних, соціально-психологічних та особистісних статусів учасників комунікації. Відзначено, що при цьому іншомовний характер комунікації накладає на неї ще й додаткову специфіку - соціально-лінгвістичну й соціокультурну. 3'ясовано праксеологічний контекст іншомовної підготовки майбутніх фахівців соціальної сфери; визначено асоціативний ряд практичної діяльності та суміжних понять (взаємодія, спілкування, життєтворчість, динамічні зміни) у контексті іншомовної комунікативної діяльності майбутніх фахівців соціальної сфери. Дослідження діяльнісного аспекту іншомовної комунікативної діяльності уможливило обгрунтування взаємозв'язку елементарних компонентів комунікації та іншомовної комунікативної діяльності майбутніх фахівців соціальної сфери.

\section{СПИСОК ВИКОРИСТАНИХ ДЖЕРЕЛ ТА ЛІТЕРАТУРИ}

1. Бахтин М. М. Проблема текста в лингвистике, филологии и других гуманитарных науках. Опыт философского анализа / М. М. Бахтин // Эстетика словесного творчества.- М. : Искусство, 1979. - С. 281328.

2. Бацевич Ф. С. Нариси з комунікативної лінгвістики : [монографія] / Ф. С. Бацевич. - Львів : Видавничий центр ЛНУ ім. Івана Франка, 2003. - 281 с.

3. Beaugrande R. De. Linguistic Theory: The Discourse of Fundamental Works / R. De. Beaugrande. - London : Longmans, 1991.

4. Dijk T. A. van. Text and Context Explorations in the Semantics and Pragmatics of Discourse / T. A. van. Dijk. London-New York : Longman, 1977.

5. Леонтьев А. А. Язык, речь, речевая деятельность / А. А. Лонтьев. - М. : Просвещение, 1969. - 214 с.

6. Morson G. Mikhail Bakhtin Creation of a Prosaics / G. Morson, E. Caryl. - Stanford, California : Stanford University Press, 1990.

7. Chomsky N. Aspects of the Theory of Syntax / N. Chomsky. - Cambridge : The M.T.T. Press, 1967.

8. Богданов В.В.Коммуникативная компетенция и коммуникативное лидерство / В.В.Богданов // Язык, дискурс и личность. : [Межвуз. сб. науч. тр.]. - Тверь, 1990. - С. 47-63.

9. Вольфовська Т. Комунікативна компетентність молоді як одна із передумов досягнення життєвої мети / Т. Вольфовська // Шлях освіти. - 2001. - № 3. - С. 13-16.

10. Гез Н. И. Формирование коммуникативной компетенции как объект зарубежных методических исследований / Н. И. Гез // Иностранные языки в школе. - 1985. - № 2. - С. 17-24.

11. Колодько Т. М. Формування соціокультурної компетенції майбутніх учителів іноземних мов у вищих педагогічних навчальних закладах : автореф. дис.... канд. пед. наук : 13.00 .04 / Т. М. Колодько. - Київ, 2005. $-24 \mathrm{c}$.

12. Мамчур Л. І. Мовна і комунікативна компетентність особистості : суть і характерні ознаки / Л. І. Мамчур. Режим доступу : http://ps.stateuniversity.ks.ua/file/issue 42/43.pdf. - 04.12.2018.

13. Hymes D. H. On Communicative Competence / D. H. Hymes. - Philadelphia : University of Pennsylvania Press, 1971. -213 p.

14. Шумарова А. Н. Мовна компетенція особистості в ситуації білінгвізму / А. Н. Шумарова. - К. : КДЛУ, 2000. $-284 \mathrm{c}$.

15. Рубинштейн С. Л. Основы общей психологии / С. Л. Рубинштейн. - СПб. : Питер, 2002. - 720 с.

16. Батищев Г. С. Введение в диалектику творчества / Г. С. Батищев. - СПб: Изд-во РХГИ, 1997. - 464 с.

17. Юдин Э. Г. Методология науки. Системность. Деятельность / Э. Г. Юдин. - М. : Эдиториал УРСС, 1997. $444 \mathrm{c}$.

18. Брушлинский А. В. Деятельностный подход и психологическая наука / А. В. Брушлинский // Вопросы философии. - 2001. - № 2. - С. 89-95.

19. Давыдов В. В. О понятии развивающего обучения : сб. статей / В. В. Давыдов. - Томск : Пеленг, 1995. $144 \mathrm{c}$.

20. Зязюн І. А. Освітня парадигма - тип культурно-історичного мислення і творчої дії суб'єктів освіти / І. А. Зязюн // Педагогіка і психологія професійної освіти: результати досліджень і перспективи : [зб. наук. пр.]. - 2003. - №2. - С. 15-30.

21. Освітні технології : [навч.-метод. посіб.] / О. М. Пехота, А. З. Кіктенко, О. М. Любарська [та ін.] ; за ред. О. М. Пєхоти. - К. : Вид-во А.С.К., 2003. - 255 с.

22. Боровских А. В. Категория деятельности и деятельностные принципы в педагогике / А. В. Боровских, Н. Х. Розов // Вопросы философии. - 2012. - № 5. - С. 90-102.

23. Богин Г.И. Филологическая герменевтика : [учеб. пос.] / Г. И. Богин. - Калинин : Калининский гос. ун-т, 1982. $-88 \mathrm{c}$. 
24. Мартинюк Т. С. Методика реалізації діяльнісного підходу у процесі навчання географії України учнів 8-9 класів : дис. ... кандидата педагогічних наук : 13.00.02 / Мартинюк Тетяна Сергіївна. - Київ, 2016. -270 с.

25. Норман Б. Ю. Проблема происхождения человеческого языка / Б. Ю. Норман // Основы языкознания. - 1996. - C. $70-86$.

26. Тєлєжкіна О. О. Ділове спілкування: усна і писемна форми / О. О. Тєлєжкіна, Н. О. Лисенко, О. О. Кушнір, О. О. Литвиненко, Н. О. Піддубна. - Х. : "Смугаста типографія", 2015. - 384 с.

27. Федчик В. А. Комунікативна діяльність у світлі поглядів сучасної науки на загальну теорію діяльності $\begin{array}{llllll}\text { [Електронний } & \text { ресурс]/ } & \text { В. А. Федчик. } & - & \text { Режим }\end{array}$ http://www.rusnauka.com/13.DNI_2007/Philologia/20061.doc.htm.

\section{REFERENCES (TRANSLATED\&TRANSLITERATED)}

1. Bakhtin M. M. Problema teksta v lingvistike, filologii i drugikh gumanitarnykh naukakh. Opyt filosofskogo analiza [The Problem of Text in Linguistics, Philology and Other Humanities. Experience Philosophical Analysis] // M. M. Bakhtin // Estetika slovesnogo tvorchestva [Aesthetics of Verbal Creativity]. - M. : Iskusstvo, 1979. S. 281-328.

2. Batsevych F. S. Narysy z komunikatyvnoi linhvistyky [Essays on Communicative Linguistics] : [monohrafiia] / F. S. Batsevych. - Lviv : Vydavnychyi tsentr LNU im. Ivana Franka, 2003. - 281 s.

3. Beaugrande R. De. Linguistic Theory : The Discourse of Fundamental Works / Beaugrande R. de. - London : Longmans, 1991.

4. Dijk T. A. van. Text and Context Explorations in the Semantics and Pragmatics of Discourse / Dijk T.A. van.London-New York : Longman, 1977.

5. Leontiev A. A. Yazyk, rech', rechevaia deiatel'nost [Language, Speech, Speech Activity] / A. A. Leontiev. - M. : Prosveschenie, 1969. - $214 \mathrm{~s}$.

6. Morson G. Mikhail Bakhtin Creation of a Prosaics / G. Morson, E. Caryl. - Stanford, California : Stanford University Press, 1990.

7. Chomsky N. Aspects of the Theory of Syntax / N. Chomsky. - Cambridge : The M.T.T. Press, 1967.

8. Bogdanov V. V. Kommunikativnaia kompetentsiia i kommunikativnoe liderstvo [Communicative Competence and Communicative Leadership] / V. V. Bogdanov // Yazyk, diskurs i lichnost' [Language, Discourse and Personality] : [Mezhvuz. sb. nauch. tr.] - Tver, 1990. - S. 47-63.

9. Volfovska T. Komunikatyvna kompetentnist' molodi yak odna iz peredumov dosiahnennia zhyttievoi mety [The communicative Competence of Youth as One of the Prerequisites for the Achievement of the Goal of Life] / T. Volfovska // Shliakh osvity [Way of Education]. - 2001. - № 3. - S. 13-16.

10. Gez N. I. Formirovanie kommunikativnoi kompetentsii kak ob'ekt zarubezhnykh metodicheskikh issledovanii [Formation of Communicative Competence as an Object of Foreign Methodological Research] / N. I. Gez // Inostrannyie yazyki v shkole [Foreign Languages at School]. - 1985. - № 2. - S. 17-24.

11. Kolodko T. M. Formuvannia sotsiokul'turnoi kompetentsii maibutnikh uchyteliv inozemnykh mov u vyshchykh pedahohichnykh navchal'nykh zakladakh [Formation of the Sociocultural Competency of Prospective Teachers at Higher Pedagogical Educational Institutions] : avtoref. dys.... kand. ped. nauk : 13.00.04 / T. M. Kolodko. - Kyiv, 2005. $-24 \mathrm{~s}$.

12. Mamchur L. I. Movna i komunikatyvna kompetentnist' osobystosti : sut' i kharakterni oznaky [Language and Communicative Competence of the Individual: the Essence and Characteristic Features] / L. I. Mamchur. -Rezhym dostupu : // http://ps.stateuniversity.ks.ua/file/issue 42/43.pdf. - 04.12.2018.

13. Hymes D. H. On Communicative Competence / D. H. Hymes. - Philadelphia : University of Pennsylvania Press, 1971. $-213 \mathrm{p}$.

14. Shumarova A. N. Movna kompetentsiia osobystosti v sytuatsii bilinhvizmu [Language Competence of Personality in the Situation of Bilingualism] / A. N Shumarova. - K. : KDLU, 2000. - $284 \mathrm{~s}$.

15. Rubinshteyn S. L. Osnovy obschei psikhologii [Fubdamentals of General Psychology] / S. L. Rubinshteyn. - SPb. : Piter, 2002. $-720 \mathrm{~s}$.

16. Batischev G. S. Vvedenie v dialektiku tvorchestva [Introduction to the Dialectic of Creativity] / G. S. Batischev. SPb. : Izd-vo RHGI, 1997. - $464 \mathrm{~s}$.

17. Yudin E. G. Metodologiia nauki. Sistemnost'. Deiatel'nost [Methodology of Science. Consistency. Activity] / E. G. Yudin - M. : Editorial URSS, 1997. - 444 s.

18. Brushlinskiy A. V. Deiatel'nostnyi podhod i psihologicheskaia nauka [Activity Approach and Psychology]/ A. V. Brushlinskiy // Voprosyi filosofii [Philosophy Questions]. - 2001. - № 2. - S. 89-95.

19. Davyidov V. V. O ponyatii razvivayuschego obucheniia [About the Concept of Developmental Learning] : [sb. statei] / V. V. Davyidov. - Tomsk : Peleng, 1995. - $144 \mathrm{~s}$.

20. Ziaziun I. A. Osvitnia paradyhma - typ kul'turno-istorychnoho myslennia i tvorchoi dii subiektiv osvity [Educational Paradigm - a Type of Cultural-Historical Thinking and Creative Action of the Subjects of Education] / I. A. Ziaziun // Pedahohika i psykholohiia profesiinoi osvity: rezul'taty doslidzhen' i perspektyvy [Pedagogy and Psychology of Vocational Education : Research Results and Perspectives] : [zb. nauk. pr.]. - 2003. - №2. - S. 1530 .

21. Osvitni tekhnolohii [Educational Technologies] : [navch.-metod. posib.] / O. M. Piekhota, A. Z. Kiktenko, O. M. Liubarska [ta in.] ; za red. O. M. Piekhoty. - K. : Vyd-vo A.S.K., 2003. -255 s.

22. Borovskikh A. V. Kategoriia deiatel'nosti i deiatel'nostnyie printsipy v pedagogike [Category of Activity and Activity Principles in Pedagogy] / A. V. Borovskikh, N. H. Rozov // Voprosy filosofii [Philosophy Questions]. 2012. - № 5. - S. 90-102. 
23. Bogin G. I. Filologicheskaia germenevtika [Philological Hermeneutics] : [ucheb. pos.] / G. I. Bogin. - Kalinin : Kalininskii gos. un-t, 1982. $-88 \mathrm{~s}$.

24. Martyniuk T. S. Metodyka realizatsii diial'nisnoho pidkhodu u protsesi navchannia heohrafii Ukrainy uchniv 8-9 klasiv [Methods of Implementation Activity Approach in Teaching Geography Studets Ukraine 8-9 Years] : dys. ... kandydata pedagogichnykh nauk : 13.00.02/ Martyniuk Tetiana Serhiivna. - Kyiv, 2016. - $270 \mathrm{~s}$.

25. Norman B. Yu. Problema proishozhdeniia chelovecheskogo yazika [The Problem of the Origin of the Human Language] / B. Yu. Norman // Osnovy yazykoznaniia [Basics of Linguistics]. - 1996. - S. 70-86.

26. Tieliezhkina O. O. Dilove spilkuvannia : usna i pysemna formy [Business Communication: Oral and Written Forms] / O. O. Tieliezhkina, N. O. Lysenko, O. O. Kushnir, O. O. Lytvynenko, N. O. Piddubna. - Kh. : "Smuhasta typohrafiia", 2015. - $384 \mathrm{~s}$.

27. Fedchyk V. A. Komunikatyvna diial'nist u svitli pohliadiv suchasnoi nauky na zahal'nu teoriiu diial'nosti [Communicative Activity in the Light of the Views of Modern Science on the General Theory of Activity] $\begin{array}{llllll}\text { [Elektronnyi } & \text { resurs] / } & \text { V. A. Fedchyk. } & - & \text { Rezhym dostupu : }\end{array}$ http://www.rusnauka.com/13.DNI_2007/Philologia/20061.doc.htm.

Павелкив Е. Н. Иноязычная подготовка специалистов социальной сферы в свете деятельностного подхода.

В статье рассмотрено сущность и содержание деятельностного подхода к иноязычной коммуникативной деятельности будущцх специиалистов социильной сферы. Обоснована сущцноть иноязычной коммуникации как особенного вида деятельности под влиянием когнитивных, социальнопсихологических и личностных статусов участников коммуникации. Отмечается, что в таком случае иноязычный характер коммуникации накладывает на нее дополнительную специфику -

социолингвистическую и социокультурную. Определен праксеологический контекст иноязычной подготовки будущих специиалистов социальной сферы, определен ассоциативный ряд практической деятельности и близких к ней понятий (взаимодействие, общение, жизнетворчество, динамические изменения) в контексте иноязычной коммуникативной деятельности будущих специалистов социальной сферы. Изучение деятельностного аспекта иноязычной коммуникативной деятельности позволило обосновать взаимосвязь элементарных компонентов коммуникации и иноязычной коммуникативной деятельности будущих специиалистов сочуиальной сферы.

Ключевые слова: деятельность, коммуникация, будущие специалисты сочииальной сферы, иноязычная коммуникативная деятельность.

\section{Pavelkiv E. M. External Preparation of Social Sphere Professionals In the Light of Activity Approach.}

The article deals with the content and essence of the activity approach to the foreign communicative activities of prospective specialists in the social sphere. The essence of foreign communication as a special kind of activity under the influence of cognitive, social-psychological and personal statuses of communication participants is substantiated. It is noted that the foreign language of communication imposes on it an additional specificitysocial-linguistic and sociocultural in this case.

The practical context of the foreign language training of prospective specialists in the social sphere is determined; the associative series of practical activity and related concepts (interaction, communication, lifecreation, dynamic changes) are defined in the context of the foreign-language communicative activity of future specialists in the social sphere. The investigation of the activity aspect of foreign communication activities enabled the substantiation of the interconnection of the elementary components of communication and other language communication activities of prospective specialists in the social sphere.

Key words: activity, communication, specialists of social sphere, foreign language communicative activity. 